УДК 658.5

\title{
ОКРЕМІ АСПЕКТИ ОЦІНКИ ІНВЕСТИЦІЙНОЇ ПРИВАБЛИВОСТІ СУБ'ЄКТІВ АГРОБІЗНЕСУ
}

\section{PARTICULAR ASPECTS OF ASSESSING THE INVESTMENT ATTRACTIVENESS OF AGRIBUSINESS ENTITIES}

\author{
Шиян Наталія Іванівна \\ доктор економічних наук, доцент, \\ Державний біотехнологічний університет (м. Харків) \\ ORCID: https://orcid.org/0000-0002-0625-8534
}

\author{
Shyian Nataliia \\ State Biotechnological University
}

\begin{abstract}
У статті визначено актуальність проблеми інвестиційної привабливості, проаналізовано теоретичні підходи до їі розгляду. Особливу увагу приділена поширеним у практиці інвесторів підходам до визначення рівня інвестиційної привабливості країни, регіону, галузі, підприємства. Здійснено оцінку інвестиційної привабливості підприємств аграрної сорери економіки, зокрема підприємств, які спеціалізуються на виробництві продукції галузі рослинництва та які виробляють одночасно і продукцію рослинництва, і продукцію тваринництва. Результати дослідження свідчать, що на сучасному етапі розвитку аграрної сфери економіки України вищою $є$ інвестиційна привабливість підприємств, які спеціалізуються на виробництві продукції рослинницької галузі, що створює проблему формування механізму підтримки розвитку тваринництва в них із боку держави, регіонів, органів місцевого самоврядування для підвищення рівня інвестиційної привабливості таких підприємств.
\end{abstract}

Ключові слова: інвестиційна привабливість, капіталовкладення, аграрні підприємства, фрінансовий стан, еорективність.

В статье определена актуальность проблемы инвестиционной привлекательности, проанализированы теоретические подходы к ее рассмотрению. Особое внимание уделено распространенным в практике инвесторов подходам к определению уровня инвестиционной привлекательности государства, региона, отрасли, предприятия. Осуществлена оценка инвестиционной привлекательности предприятий аграрной сореры экономики, в т.ч. предприятий, которые специализируются на производстве продукции отрасли растениеводства и тех предприятий, которые одновременно производят продукцию растениеводства и животноводства. Результаты исследования свидетельствуют, что на данном этапе развития аграрной сореры экономики Украины более высокую инвестиционную привлекательность имеют предприятия, которые специализируются на производстве продукции отрасли растениеводства, что создает проблему формирования механизма поддержки развития отрасли животноводства в них со стороны государства, регионов, органов местного самоуправления с целью повышения уровня инвестиционной привлекательности таких предприятий.

Ключевые слова: инвестиционная привлекательность, капиталовложения, аграрные предприятия, фринансовое состояние, эффрективность.

The article determines the relevance of the problem of investment attractiveness, analyzes the theoretical approaches to its consideration. Particular attention is paid to common in the practice of investors approaches to determining the level of investment attractiveness of the state, region, industry and enterprise. It was defined that the level of investment attractiveness is determined as an integral indicator with the addition of a set of indicators, which identify the characteristics of the sphere of activity, geographical location, strategic intentions, etc. Particular attention was paid to the index of investment attractiveness of Ukraine in accordance with the methodology of the European business organization. The factors and peculiarities of determining the investment attractiveness of the agrarian sphere were specified. The estimation of the investment attractiveness of enterprises of the agrarian sector of the economy with the use of data on the financial condition and efficiency of enterprises in the Kharkiv region in 2020 , including enterprises that specialize in the production of crop production and those enterprises that simultaneously produce crop and livestock production was carried out. The results of the study indicate that at this stage of development of the agrarian sector of the economy of Ukraine the enterprises that specialize in the field of crop 
production have higher investment attractiveness, which creates a problem of forming a mechanism to support the development of animal husbandry in them by the state, regions and local governments to increase the investment attractiveness of such enterprises.

Keywords: investment attractiveness, capital investments, agrarian enterprises, financial condition, efficiency.

Постановка проблеми. Розвиток аграрного сектора економіки країни був і залишається одним 3 пріоритетних. Сприятливі кліматичні умови, якісні земельні ресурси, які становлять основу виробництва аграрної продукції, вдале розташування на перетині транспортних шляхів з Європи в Азію, зі Скандинавських країн у країни Середземноморського регіону свідчать про існування потенціалу та перспективи розвитку сільського господарства України. Але стан розвитку аграрного сектора України залишається складним. Його характерними рисами є превалювання в структурі виробництва аграрної продукції галузі рослинництва насамперед, зернових і технічних культур; суттєве зменшення поголів'я худоби в галузі тваринництва, у т.ч. поголів'я ВРX, свиней; зменшення площ сінокосів, пасовищ; недостатній рівень прибутковості, який у сучасних умовах діяльності суб'єктів агробізнесу є одним з мотивуючих показників розвитку сорери. Водночас, поглибилися проблеми, пов'язані із безробіттям на селі, недостатнім рівнем доходів сільського населення, міграцією склян до міст і в інші країни.

Поліпшенню стану розвитку аграрного сектора економіки країни сприятиме підвищення рівня його інвестиційної привабливості, фрормування умов залучення інвестицій як потужної основи для використання інновацій під час виробництва, зберігання, транспортування аграрної продукції; підвищення рівня її конкурентоспроможності, якості, безпеки; фрормування і створення умов для отримання рівня аграрної освіти, який би відповідав сучасним вимогам до розвитку конкурентоспроможного аграрного виробництва; збільшення чисельності сільського населення, підвищення рівня його добробуту та ін. Тобто проблема оцінки інвестиційної привабливості та пошуку напрямів її підвищення набуває актуальності і для підприємств, які зацікавлені в отриманні інвестицій, і для інвесторів, для яких важливим $€$ отримання віддачі від вкладень у галузь.

Аналіз останніх досліджень і публікацій. Аналіз праць науковців свідчить про детальний розгляд проблеми визначення сутності інвестицій, особливостей механізмів їх залучення на фрінансовому ринку, підходів до оцінки інвестиційної привабливості, формування основ для створення сприятливого середовища на рівні економіки країни, регіонів, галузей [12; 15-17; 21-22; 28]. Акцентуючи у своїх роботах увагу на визначенні основ інвестиційної діяльності, механізмах інвестування, фрормуванні сприятливого інвестиційного клімату, автори чітко фрормулюють сутність поняття «інвестиційна привабливість», застосовуючи конкретні підходи до ії̈ вивчення.

Розуміючи під інвестиційною привабливістю багаторівневу систему, яка включає країну, галузь, регіон, підприємство та окремі види виробництва, розглядаємо під цим поняттям агрегований показник, який, на думку О. Кундеуса, дозволяє в комплексі оцінити переваги від економіки країни до окремого виробництва і прийняти правильне рішення щодо інвестування [22]. Погоджуючись із цим тлумаченням, зауважимо, що підходи до визначення інвестиційної привабливості визначають і за ієрархічним рівнем об'єкта такої оцінки, і за особливостями сфери його діяльності.

Зокрема, у практиці інвесторів, які вбирають країну для інвестування, набув поширення підхід до визначення інвестиційної привабливості 3 використанням Індексу інвестиційної привабливості країни (GFICA) [1], в основу якого покладено також дані за країнами світу, які надають Світовий банк (The Worldwide Governance Indicators), The conference Board (The Conference Board Data Central), International Monetary Fund (World Economic Outlook, Global Financial Stability Report, Fiscal Monitor), міжнародні рейтингові агентства та ін. [1-6; 8-11].

Результати досліджень науковців свідчать, що величина Індексу інвестиційної привабливості країн світу (GFICA) визначається високим рівнем взаємозв'язку між цим Індексом та розміром прямих іноземних інвестицій $(0,69)$, інвестицій в основний капітал $(0,75)$. Тому, вирішуючи питання пошуку чинників, спрямованих на його підвищення, потрібно звернути увагу на існування такого тісного взаємозв'язку під час розробляння Програм розвитку країни, галузей, виробництв.

Визначаючи чинники, що фрормують рівень інвестиційної привабливості України, відмітимо, що позитивний інвестиційний клімат України, як потенційного реципієнта, на 
думку О. Ткаченка, фрормують сприятливе географрічне розташування країни, сприятливі для ведення сільського господарства умови; достатньо високий рівень кваліфікації працівників і менеджерів різних галузей економіки; високий природно-ресурсний потенціал країни. Водночас, нестабільність політичної, економічної, правової системи в країні, високий рівень корумпованості влади, недотримання законів, непередбачуваність економічної ситуації в майбутньому, збройний конфолікт на частині території країни, нестабільність національної валюти зменшують рівень інвестиційної привабливості [25].

Індекс інвестиційної привабливості в Україні розраховують за методикою Європейської бізнес-організації (European Business Association (EBA)). За 5-бальною шкалою в першому півріччі 2021 р. він був оцінений у 2,84 бала [7]. Близько $60 \%$ респондентів (компанії, що входять до Європейської бізнес організації), вважають, що інвестиційний клімат у країні $€$ недостатньо сприятливим для розвитку бізнесу; $34 \%$ респондентів переконані в його нейтральності і лише 4\% уважають його сприятливим. Визначаючи тренди в розвитку бізнесу, респонденти виділяють серед них негативні: підвищення рівня корупції в країні, слабку судову система; падіння темпів розвитку економіки. Результатом цих процесів $€$ зниження рівня інвестиційної активності в країні.

Оцінюючи інвестиційну привабливість аграрної ссрери, науковці і практики говорять, з одного боку, про високий потенціал, з другого - її визначають як недостатню для підвищення активності інвесторів. Практики стверджують про те, що сільське господарство задихається від нестачі інвестицій. За розрахунками Інституту аграрної економіки України, сільське господарство потребує від 75 млрд грн інвестицій щороку [24]. Проте ця галузь економіки не отримує таких інвестицій.

Вважають, що надто складним із цього погляду був 2020 р. Спостерігалося зменшення річного обсягу капітальних інвестицій в сільське господарство на 14-15 млрд грн порівняно з 2019 р., що, на думку науковців, стало результатом недостатньої стабільності законодавчої бази; відсутності позитивних результатів реформ в Україні; високого рівня корумпованості; пандемії COVID-19, i, що, на наш погляд, було надто важливим - очікувань щодо ринку землі та ін. [18]. За перше півріччя 2021 р., відповідно до оприлюднених Державною службою статистики України даних, обсяги капітальних вкладень в аграрний сектор економіки становили 28,3 млрд грн, у т.ч. у сільське господарство, мисливство 19,1 млрд грн [13].

У 2021 р. очікувалася активізація інвесторів щодо аграрної сфрери, прогнозувалося поступове зростання інвестицій у неї. За оптимістичними прогнозами, обсяги капіталовкладень у цю сореру повинні були досягати 48 млрд грн [27].

Зростання інвестицій в аграрний сектор економіки дозволить створити умови для використання підприємствами нових технологій та інновацій, унаслідок чого продукція, вироблена в аграрній ссрері, буде ефективнішою, якіснішою, безпечнішою, створюватимуться умови для виробництва продукції 3 доданою вартістю.

Суттєвий вплив на фрормування інвестиційної привабливості аграрної сорери сьогодні має ринок землі з великим ступенем невизначеності щодо процесів, які розпочалися і тривають у ньому. Водночас слід звернути увагу на певні переваги, завдяки яким галузь стає інвестиційно привабливою. До таких належать: невисока вартість оренди землі; зростання цін на аграрну продукцію і продовольство; існування площ необроблених земель, що може розглядатися як можливість ведення органічного виробництва, попит на продукцію якого в Україні і країнах світу підвищується, тощо. Нині вкрай потрібна активізація інвестиційних процесів в аграрному секторі економіки, що сприятиме веденню ефективного сучасного аграрного виробництва, яке забезпечить відповідну віддачу.

На рівні суб'єктів бізнесу підходи до оцінки інвестиційної привабливості компаній залежать насамперед від мети такої оцінки: формування загального уявлення щодо інвестиційної привабливості об'єкта вкладання інвестицій; прийняття рішення стосовно доцільності реалізації інвестиційного проєкту на основі вивчення стану діяльності компанії та попиту на інвестиції з ії боку; розрахунку системи показників, які характеризують ефективність проєкту, його віддачу; аналізу ризикованості та невизначеності у його реалізації.

Інколи ці підходи поділяють на такі, які $€$ загальними, і такі, які залежать від специфріки галузі; на кількісні та якісні. Здебільшого в основу оцінювання покладено показники срінансового стану компанії та есрективності реалізовуваних нею інвестиційних проектів. Тобто оцінювання інвестиційної привабливості компанії передбачає використання не 
єдиного методичного підходу, а сукупності їх елементів, які залежать від сорери діяльності, географрічного розташування, стратегічних намірів та ін.

Визначено, що серед розповсюджених методик оцінки інвестиційної привабливості компаній набули поширення такі методичні підходи:

- 3 використанням аналізу ринкової капіталізації компанії і похідних від неї показників. Цей підхід поширений при аналізі інвестиційної привабливості компанії-емітента і доцільності вкладання коштів у її цінні папери. Тобто інвестиційну привабливість компанії, згідно із цим підходом, розглядають відповідно до привабливості її цінних паперів. Дослідження українських науковців свідчать, що використання цього підходу стосовно до українських підприємств не завжди є виправданим. Така ситуація викликана особливостями функціонування і розвитку фінансового ринку в Україні, серед яких, зокрема, слід виділити такі: здійснення угод купівлі-продажу цінних паперів обмеженого кола компаній; спрямування прибутку компанії на її розвиток, а не на сплату дивідендів; одержання основного доходу інвесторів від результатів діяльності компанії не від дивідендів, а від зростання ринкової вартості акцій; неповна об'єктивність звітних даних компанії щодо результатів її діяльності. Тому показники ринкової капіталізації компанії необхідно розглядати як частину показників, із застосуванням яких оцінюють рівень інвестиційної привабливості компанії;

- 3 використанням аналізу фрінансових та економічних показників діяльності компанії. Цей підхід достатньо поширений у практичній діяльності інвесторів і компаній. Можуть певною мірою різнитися лише показники, які беруть до уваги при характеристиці;

- з використанням інтегрального показника інвестиційної привабливості компанії, який є узагальнювальним щодо результатів діяльності компанії і сфер, які отримали свій розвиток у ній. Як правило, інтегральний показник інвестиційної привабливості базується на найбільш вагомих для інвестора фрінансовоекономічних показниках. Їх значення співвідносять $з$ еталонними значеннями показників, а вагове значення в інтегральному показнику визначає інвестор [20; 23; 26].

Як свідчать дослідження, протягом останнього періоду набули поширення характеристики діяльності компаній, які складно оцінити кількісно, а їх оцінка здійснюється через розуміння певних категорій, процесів, які відбу- ваються на рівні компанії. Ідеться про оцінку якості системи управління та процесів, які відбуваються в ній. Прикладом може бути якість корпоративної культури; ступінь інфрормаційної прозорості в компанії; склад ради директорів і менеджменту; обмеження на володіння акціями та ін. Тому представлені вище методики оцінювання інвестиційної привабливості компаній доповнюються характеристикою і аналізом якісних показників її діяльності.

Унаслідок того, що на інвестиційну привабливість впливають багато чинників і кожна зі сорер діяльності може суттєво відрізнятися, сутність цього поняття відображено в тому, що воно дає змогу оцінити, наскільки вигідними є вкладення [14].

Цікавим у визначенні інвестиційної привабливості компанії $€$ підхід Р. Каплана і Д. Нортона - авторів збалансованої системи показників ефективності організації. В основу покладено причинно-наслідкові зв'язки між стратегічними цілями компанії і фракторами, які впливають на отримання запланованих результатів, які оцінюються і поділені на такі складові: фрінансова, клієнтська, внутрішні бізнес-процеси; навчання та розвиток персоналу [19]. На думку дослідників, перевагою такої збалансованої системи є доповнення фрінансових показників сукупністю операційних, стратегічних і якісних показників, які охоплюють важливі напрями діяльності підприємства, що 3 використанням імітаційного моделювання дозволяє визначити загальний інтегральний показник інвестиційної діяльності підприємства. Інтерпретація інтегрального показника здійснюється відповідно до шкали Харрінгтона (0,8-1,0 - дуже високий рівень; 0,64-0,8 високий; 0,37-0,64 - середній; 0,2-0,37 - низький; 0,0-0,2 - дуже низький).

Важливою в оцінюванні інвестиційної привабливості є оцінка ризику, який може бути представлений зниженням доходу, зміною політики ціноутворення на рівні компанії, кон'юнктури ринку, втратою ліквідності, невиконанням зобов'язань та ін.

Результати аналізу свідчать, що в цілому в науковій літературі сорормовано бачення щодо сутності поняття «інвестиційна привабливість», підходів до її оцінки, пов'язаних 3 ієрархічним рівнем та сорерою діяльності об'єкта такої оцінки, визначенням чинників, які впливають на неї. Але залишається актуальним подальший розгляд існуючих підходів щодо оцінки інвестиційної привабливості 3 визначенням їх особливостей саме стосовно аграрної сорери економіки. 
Формулювання цілей статті (постановка завдання). Метою статті $€$ підтвердження або спростування гіпотези про різний ступінь інвестиційної привабливості тих аграрних підприємств, які в сучасних умовах спеціалізуються на виробництві продукції галузі рослинництва, а також тих, які, крім рослинницької, виробляють і продукцію галузі тваринництва.

Виклад основного матеріалу дослідження. Чинником, що впливає на обрання методики оцінювання інвестиційної привабливості підприємства, є мета здійснюваної оцінки. У нашому дослідженні при оцінці рівня інвестиційної привабливості аграрних підприємств інвестиційну привабливість розглянуто 3 погляду фрормування інвестиційного портфреля інвестора і доцільності його вкладень в аграрні підприємства. В основу оцінки покладено як показники, які визначають фрінансовий стан (коефріцієнт ліквідності, частка власних коштів у пасивах, рентабельність активів та ін.), так і показники, які характеризують особливість сорери їх діяльності - аграрної сорери економіки (площа сільськогосподарських угідь, товарна продукція і прибуток на 100 га сільськогосподарських угідь).

У процесі дослідження було проаналізовано дані по сільськогосподарських підприємствах Харківської області, які надавали фрінансову звітність у 2000 р. Окремі фрінансові показники діяльності аналізованих нами аграрних підприємств у цілому, зокрема підприємств, які спе- ціалізуються на виробництві продукції галузі рослинництва, та підприємств, які виробляють продукцію галузі рослинництва і тваринництва одночасно, наведено в табл. 1.

Аналіз отриманих розрахункових даних свідчить, що нижчими $є$ значення розрахованих нами показників по останній групі підприємств, які поєднують виробництво продукції галузей рослинництва і тваринництва. Наприклад, коефіцієнт оборотності активів, як показник ділової активності, який дає уявлення про те, скільки продукції реалізує підприємство, залежно від наявності у нього активів, для всієї сукупності аналізованих сільськогосподарських підприємств дорівнював 0,62 грн на кожну гривню активів. Зокрема, по сукупності підприємств, які займаються лише виробництвом продукції рослинництва, коефріцієнт оборотності активів дорівнював 0,61, а в сукупності підприємств, які, крім продукції рослинництва, виробляли і продукцію тваринництва, був меншим - лише 0,45.

Характеризуючи показник, доцільно розглядати його в динаміці, а також порівнюючи з конкурентами. Якщо спостерігається збільшення показника при вищих темпах зростання виручки від реалізації продукції порівняно $з$ темпами збільшення середньорічної величини вартості активів, можна говорити про позитивну його динаміку. У разі зменшення значення показника при невисоких темпах зростання виручки від реалізації про-

\section{Окремі показники фрінансового стану аграрних підприємств Харківської області у 2020 р.}

Таблиця 1

\begin{tabular}{|c|c|c|c|c|}
\hline \multirow{2}{*}{$\begin{array}{c}\text { Пор. } \\
\text { № }\end{array}$} & \multirow{2}{*}{ Показник } & \multirow{2}{*}{$\begin{array}{c}\text { По усій } \\
\text { сукупності } \\
\text { с.-г. } \\
\text { підприємств }\end{array}$} & \multicolumn{2}{|c|}{$\begin{array}{c}\text { Фактичне значення показника по } \\
\text { підприємствах із розвитком галузі }\end{array}$} \\
\hline & & & рослинництва & $\begin{array}{l}\text { рослинництва } \\
\text { і тваринництва }\end{array}$ \\
\hline 1 & Коесріцієнт оборотності активів & 0,62 & 0,61 & 0,45 \\
\hline 2 & Фондовіддача & 2,67 & 2,68 & 1,61 \\
\hline 3 & $\begin{array}{l}\text { Коефріцієнт оборотності власного } \\
\text { капіталу }\end{array}$ & 1,016 & 0,956 & 0,565 \\
\hline 4 & Рентабельність активів (ROA), \% & 12,8 & 13,1 & 7,0 \\
\hline 5 & Рентабельність реалізації (ROS), \% & 20,7 & 21,7 & 15,4 \\
\hline 6 & $\begin{array}{l}\text { Рентабельність власного } \\
\text { капіталу (ROE), \% }\end{array}$ & 20,3 & 20,8 & 8,7 \\
\hline 7 & Окупність власного капіталу & 4,9 & 4,8 & 11,5 \\
\hline 8 & Коесріцієнт платоспроможності & 1,688 & 1,668 & 1,645 \\
\hline 9 & Коесріцієнт абсолютної ліквідності & 0,166 & 0,165 & 0,062 \\
\hline 10 & Рентабельність за EBITDA, \% & 67,9 & 68,4 & 56,9 \\
\hline 11 & Debt/Equity (борг/власний капітал) & 0,564 & 0,577 & 0,244 \\
\hline 12 & Коефріцієнт фрінансової стійкості & 0,758 & 0,755 & 0,824 \\
\hline
\end{tabular}


дукції порівняно з темпами зростання середньорічної величини активів компанії потрібно звернути увагу на оптимізацію цих активів (зменшити суму запасів, вжити заходів для повернення дебіторської заборгованості та ін.). У сукупності все це сприятиме зростанню коефріцієнта оборотності активів.

Аналіз показника фрондовіддачі демонструє есрективність використання основних засобів підприємства, і здійснювати такий аналіз доцільно в динаміці, порівняно з підприємствами-конкурентами. Звичайно, залежно від сорери діяльності компанії значення показника фондовіддачі змінюється. У фрондомістких компаніях воно $€$ меншим. Середнє значення цього показника за аналізованою сукупністю аграрних підприємств Харківської області у 2020 р. становило 2,67, у підприємствах, які виробляли лише продукцію рослинництва, $-2,68$, а в підприємствах, які поряд із рослинницькою виробляли і продукцію галузі тваринництва, - лише 1,61, тобто в цій групі воно було найнижчим, проте вищим від 1, що важливо з погляду досягнення нормативного значення показника.

Коефіцієнт оборотності власного капіталу підприємства, який дає уявлення про ефективність управління його власним капіталом, указує на те, якою $є$ кількість продукції (послуг), проданої на кожну гривню залучених від власників коштів. У наших розрахунках середня за сукупністю аналізованих підприємств величина цього коефріцієнта була невисокою - 1,016. Водночас вона суттєво коливалася за підприємствами. Величина коефріцієнта варіації досягла 659,1\%, що може бути свідченням значної різниці цього показника за підприємствами внаслідок їх суттєвої відмінності за розмірами, фрормою власності і господарювання. У сукупності підприємств, які виробляли лише продукцію галузі рослинництва, величина коефріцієнта оборотності власного капіталу становила 0,956, а в тих із них, які поряд із продукцією галузі рослинництва виробляли продукцію тваринництва 0,565, тобто майже в 1,8 раза менше.

Показник рентабельності активів (ROA) дозволяє визначити есрективність використання активів компанії для генерації ії прибутку. Його величина по сукупності підприємств Харківської області становила 12,8\%, у групі підприємств із виробництвом продукції галузі рослинництва - 13,1, а в останній групі вона була найменшою і досягла лише 7,0\%.

Величина показника рентабельності реалізації характеризує доходність основної діяльності підприємства у вигляді суми прибутку з кожної гривні реалізації, повинна бути більшою від 1. Унаслідок того, що величина чистого прибутку підприємства утворюється під впливом сукупності чинників, які перебувають в операційній, орінансовій, інвестиційній сорерах, вважають, що оптимізація структури орінансових ресурсів компаній, зниження вартості їх залучення та витрат на виробництво товарів, використання податкових пільг дозволить підвищити показник рентабельності реалізації. Розраховане значення цього показника за сукупністю підприємств із виробництвом продукції галузі рослинництва досягло 20,7\%, за групою підприємств із виробництвом продукції рослинництва і тваринництва - 15,4\%. Тобто показник рентабельності реалізації в обох випадках був достатньо високим, проте в підприємствах, які виробляли продукцію і галузі рослинництва, і тваринництва, його величина була нижчою.

Підтверджують висновок щодо нижчого показника, який характеризує фрінансовий стан діяльності підприємств, які виробляють поряд із рослинницькою продукцією продукцію галузі тваринництва, і показники, розраховані нижче. Зокрема, коефріцієнт рентабельності власного капіталу, який $€$ важливим індикатором для власників компанії і може бути використаним при оцінці вартості акцій компанії, розрахунку величини очікуваних дивідендів, у досліджуваних сукупностях підприємств становив 21,7 і 15,4\%. У підприємствах із галуззю тваринництва він був нижчим на 5,3 в.п.

Відомо, що вищі значення показника за умов стабільності величини власного капіталу свідчитимуть про підвищення здатності підприємства генерувати прибуток власникам. У разі зменшення власного капіталу підприємства може спостерігатися зростання величини рентабельності власного капіталу, що може означати, що підприємство використовує кредитний капітал замість власного як джерело фрінансування. Тому потрібно розглядати показник в динаміці і відслідковувати, як вони впливають на розраховане значення.

3 погляду власників підприємства важливим $€$ і показник окупності власного капіталу. Він дозволяє визначити період, протягом якого власний капітал окупиться величиною чистого прибутку. Вважають, що визначення нормативного значення величини окупності власного капіталу залежить від уявлень власників підприємства. У нашому випадку величина окупності власного капіталу в середньому по аграрних підприємствах Харківської 
області у 2020 р. становила 4,9 року, по підприємствах 3 виробництвом продукції галузі рослинництва - 4,8, а по підприємствах 3 обома галузями вона була суттєво вищою - у 2,4 раза і становила 11,5 р. Але тривалий термін окупності власного капіталу може свідчити не на користь виробництва продукції галузі тваринництва 3 погляду фрормування фрінансових показників розвитку галузі в сучасних умовах діяльності аграрних підприємств.

Коефріцієнт платоспроможності характеризує можливості підприємства вчасно розраховуватися за своїми зобов'язаннями. Иого нормативне значення повинно бути більшим від 1. За сукупністю аналізованих нами аграрних компаній величина коесріцієнта платоспроможності у 2020 р. дорівнювала 1,668 і 1,654, що є достатньо високими значеннями.

Коефріцієнт абсолютної ліквідності відображає покриття поточних зобов'язань компанії найбільш ліквідними ії активами. Нормативом вважається значення, яке коливається від 0,1 до 0,2. Якщо воно нижче від 0,1, це може свідчити про можливість виникнення проблем $з$ погашенням боргів компанії; якщо його величина $є$ більша ніж 0,2 , це може підтвердити неефективну стратегію управління фрінансовими ресурсами. Наприклад, грошові кошти, які не залучені до виробничо-збутового процесу, не генерують доходу компанії, але збільшують чисельник - ліквідну частину активів. Тому їх велика кількість буде свідчити про відволікання частини капіталу на фрормування непродуктивних активів).

За сукупністю аналізованих нами компаній 3 виробництва продукції галузі рослинництва коефріцієнт абсолютної ліквідності становив 0,165, що свідчить про його достатню величину. Водночас у підприємствах, які в структурі товарної продукції мають і продукцію галузі тваринництва, величина коесріцієнта абсолютної ліквідності досягла лише 0,062, тобто була недостатньою.
Цікавим з погляду інвестиційної привабливості компаній $є$ показник рентабельності за EBITDA - це розмір прибутку до вирахування відсотків, податків і величини амортизаційних відрахувань. Рентабельність за EBITDA характеризує процент від виручки, який зберігається компанією до сплати податків, відсотків за кредитами, амортизації. Чим вищим він $€$, тим вища ефрективність компанії. За сукупністю аналізованих нами компаній його величина становила 68,4 і $56,9 \%$, тобто була достатньо високою. У підприємствах із галуззю тваринництва цей показник також був меншим.

Наступний показник - Debt/Equity (борг/ капітал) - дозволяє інвестору оцінити боргове навантаження компанії порівняно 3 її власним капіталом. Чим вища його величина, тим більше зобов'язань вона має. Як правило, показник не може перевищувати 1. За умов, якщо таке трапляється, активи компанії складають переважно її борги, а якщо це значення менше від 1, то -власний капітал. За аналізованими нами сукупностями значення цього показника становили 0,577 і 0,244, відповідно.

Коесріцієнт орінансової стійкості - показник, за величиною якого визначають інвестиційну привабливість підприємства в довгостроковій перспективі; його розраховують як відношення власного капіталу і довгострокових зобов'язань компанії до валюти балансу. Високе його значення свідчить про гарні перспективи розвитку компанії, низьке - про наявність ризику втрати нею платоспроможності. Нормативним $є$ його значення в межах 0,7-0,9. У групі аналізованих нами компаній величина коефріцієнта фрінансової стабільності становила 0,755 і 0,824 відповідно, тобто була у встановлених межах.

Наступним етапом дослідження став розрахунок ряду показників, які характеризують особливості сорери діяльності аграрних підприємств (табл. 2).

Таблиця 2

Окремі показники ефективності аграрних підприємств Харківської області у 2020 р.

\begin{tabular}{|c|c|c|c|c|}
\hline \multirow{2}{*}{$\begin{array}{l}\text { Пop. } \\
\text { № }\end{array}$} & \multirow{2}{*}{ Показник } & \multirow{2}{*}{$\begin{array}{c}\text { По усій } \\
\text { сукупності } \\
\text { с.-г. } \\
\text { підприємств }\end{array}$} & \multicolumn{2}{|c|}{$\begin{array}{l}\text { Фактичне значення показника по } \\
\text { підприємствах із розвитком галузі }\end{array}$} \\
\hline & & & рослинництва & $\begin{array}{l}\text { рослинництва } \\
\text { і тваринництва }\end{array}$ \\
\hline 1 & $\begin{array}{l}\text { Середня площа } \\
\text { сільськогосподарських угідь, га } \\
\text { на } 1 \text { підприємство }\end{array}$ & 4281 & 4437 & 1529 \\
\hline 2 & $\begin{array}{l}\text { Товарна продукція на } 100 \text { га } \\
\text { с.г. угідь, тис. грн }\end{array}$ & 3007 & 2994 & 2902 \\
\hline 3 & Прибуток на 100 га, тис. грн & 649,1 & 650,7 & 568,6 \\
\hline
\end{tabular}


Аналіз наведених у табл. 2 показників підтверджує, що для досліджуваних підприємств з різним напрямом діяльності характерною $€$ суттєва відмінність за площею сільськогосподарських угідь. Зокрема, середня площа сільськогосподарських угідь у підприємствах, які спеціалізуються на виробництві продукції галузі рослинництва, дорівнювала 4437 га, у підприємствах, які поряд із рослинницькою виробляли продукцію галузі тваринництва, 1529 га. Пояснити суттєву різницю у площі сільськогосподарських підприємств, які виробляли і продукцію галузі тваринництва, на наш погляд, можна тим, що, по-перше, ці підприємства взагалі значно відрізнялися за площею сільськогосподарських угідь; по-друге, такі господарства виробляли різні види тваринницької продукції: продукцію скотарства, свинарства, мед тощо, що також впливало на загальну площу підприємства.

Такі показники ефективності виробництва аграрної продукції, як товарна продукція і прибуток з розрахунку на 100 га сільськогосподарських угідь, за групами аналізованих підприємств різнилися несуттєво.

Висновки 3 дослідження і подальші перспективи в цьому напрямі. В економічній літературі сорормувалося загальне тлумачення сутності поняття «інвестиційна привабливість» та підходів до її визначення. Стосовно аграрної сфрери економіки рівень інвестиційної привабливості з погляду срормування інвестиційного портореля інвестора визначають і сукупністю показників фрінансової діяльності підприємства, і особливостями ссрери їх діяльності, ресурсами, які вони мають.

Проведений аналіз інвестиційної привабливості підприємств аграрної сорери Харківської області у 2020 р. підтвердив гіпотезу щодо вищого рівня інвестиційної привабливості тих підприємств, діяльність яких спрямована на виробництво продукції галузі рослинництва. Водночас підприємства, які займаються виробництвом рослинницької продукції при невеликих обсягах виробництва продукції галузі тваринництва, на жаль, поступаються, і в ряді випадків суттєво, за фрінансовими показниками тим підприємствам, де розвинута лише галузь рослинництва, що вимагає розробки механізму дієвої підтримки розвитку тваринницької галузі і на державному, і на регіональному рівнях.

у цілому аграрні підприємства за досліджуваною сукупністю показників фрінансового стану і показників ефрективності їх діяльності $€$ інвестиційно-привабливими для фрормування диверсифікованого портореля інвестицій.

\section{СПИСОК ВИКОРИСТАНИХ ДЖЕРЕЛ:}

1. A Global Foreign Direct Investment Country Attractiveness Index. URL: http://www.fdiattractiveness.com/

2. About Moody's Analitics. URL: https://www.moodysanalytics.com/

3. BDO International Business Compass (IBC). URL: https://eba.com.ua/ukrayina-pidvyshhyla-svoyi-pozytsiyiu-rejtyngu-investytsijnoyi-pryvablyvosti-v-2018-rotsi/

4. Bloomberg. URL: https://www.bloomberg.com/europe

5. Financial Times. URL: https://www.ft.com/todaysnewspaper

6. Fitch Ratings. URL: https://www.fitchratings.com/

7. Investment attractiveness index of Ukraine improved in H1 2021 - Ministry of Economy. URL: https://www.ukrinform.net/rubric-economy/3279625-investment-attractiveness-index-of-ukraine-improved-inh1-2021-ministry-of-economy.html

8. Les Echos. URL: https://www.lesechos.fr./

9. S\&P Global Ratings. URL: https://www.spglobal.com/ratings/en/

10. The Wall Street Journal. URL: https://www.wsj.com/

11. UNCTAD. World Investment Report. URL: https://unctad.org/topic/investment/world-investment-report

12. Бланк И.А. Инвестиционный менеджмент : учеб. пособие. Киев : Ника-Центр: Эльга-Н, 2001. 448 с.

13. В Україні зросли інвестиції в окремі агропродовольчі сектори економіки. URL: https://agropolit.com/ news/21700-v-ukrayini-zrosli-investitsiyi-v-okremi-agroprodovolchi-sektori-ekonomiki

14. Вірянська О.В. Оінка інвестиційної привабливості. URL: https://nau.edu.ua/site/variables/news/2018/5/\% D0\%A2\%D0\%B5\%D0\%B7\%D0\%B8\%202018/30-).pdf

15. Донцов С.С. Оцінка інвестиційної привабливості підприємства через аналіз надійності його цінних паперів. Фінансовий менеджмент. 2003. № 3. С. 78-84.

16. Задорожна Я.є., Дядечко Л.П. Підвищення інвестиційної привабливості підприємництва як напрямок залучення інвестиційних ресурсів. Інвестиції: практика та досвід. 2007. № 2. С. 32-35.

17. Іванов С.В. Оцінка інвестиційного потенціалу регіону. Економіка: проблеми теорії та практики : зб. наук. пр. 2004. Т. 21. № 191. С. 100-103. 
18. Капітальні інвестиції у сільське господарство у 2020 році складуть близько 36 млрд грн. URL: https://agropolit.com/news/18935-kapitalni-investitsiyi-u-silske-gospodarstvo-u-2020-rotsi-skladut-blizko-36-mlrd-grn

19. Каплан Р., Нортон Д. Сбалансированная система показателей. От стратегии к действию. Москва : Олимп-Бизнес, 2016. 320 c.

20. Козяр Н.О. Методичні підходи до оцінки інвестиційної діяльності сільськогосподарських підприємств. Агросвіт. 2019. № 16. С. 67-76.

21. Крейніна М.Н. Аналіз фінансового стану та інвестиційної привабливості акціонерних товариств у виробництві, будівництві та торгівлі. 1994. 256 с.

22. Кундеус О.М. Роль інвестиційної привабливості економіки України в залученні інвестицій. Інноваційна економіка. 2008. № 1. C. 11-15. URL: http://www.in.gov.ua/

23. Варченко О.М., Липкань О.В. Методичні підходи до оцінки інвестиційної діяльності сільськогосподарських підприємств. Інноваційна економіка. 2016. № 3-4. С. 29-38. URL: http://nbuv.gov.ua/UJRN/inek_2016_3-4_6

24. НАAН: Потреба сільського господарства в інвестиціях - принаймні 75 млрд грн на рік. URL: http://naas.gov.ua/slide/naan-potreba-s-Iskogo-gospodarstva-v-nvestits-yakh-prinaymn-75-mlrd-grn-na-r-k/

25. Ткаченко О.М. Оцінка інвестиційної привабливості України крізь призму міжнародних рейтингів. Інвестиції: практика та досвід. 2018. № 11. C. 15-21. URL: http://www.investplan.com.ua/pdf/11_2018/5.pdf

26. Ткачук І.І., Спіцина Ю.Г. Сутніть поняття «інвестиційна привабливість підприємства». Економіка та управління підприємствами. Проблеми системного підходу в економіці. 2018. Вип. 5(67). С. 124-129.

27. У 2021 році в АПК очікується інвестиційний сплеск. URL: https://agrotimes.ua/agromarket/u-2021-roczi-vapk-ochikuyetsya-investyczijnyj-splesk/

28. Шарп У.Ф., Александер Г.Дж., Бэйли Дж. В. Инвестиции : учебник. Москва : ИНФРА-М, 2001. 1035 с.

\section{REFERENCES:}

1. A Global Foreign Direct Investment Country Attractiveness Index. Available at: http://www.fdiattractiveness.com/

2. About Moody's Analitics. Available at: https://www.moodysanalytics.com/

3. BDO International Business Compass (IBC). Available at: https://eba.com.ua/ukrayina-pidvyshhylasvoyi-pozytsiyi-u-rejtyngu-investytsijnoyi-pryvablyvosti-v-2018-rotsi/

4. Bloomberg. Available at: https://www.bloomberg.com/europe

5. Financial Times. Available at: https://www.ft.com/todaysnewspaper

6. Fitch Ratings. Available at: https://www.fitchratings.com/

7. Investment attractiveness index of Ukraine improved in $\mathrm{H} 12021$ - Ministry of Economy. Available at: https://www.ukrinform.net/rubric-economy/3279625-investment-attractiveness-index-of-ukraine-improved-in-h12021-ministry-of-economy.html

8. Les Echos. Available at: https://www.lesechos.fr./

9. S\&P Global Ratings. Available at: https://www.spglobal. com/ratings/en/

10. The Wall Street Journal. Available at: https://www.wsj.com/

11. UNCTAD. World Investment Report. Available at: https://unctad.org/topic/investment/world-investment-report

12.Blank I.A. (2001) Investitsionnyiy menedzhment: ucheb. posobie. Kiev: Nika-Tsentr: Elga-N, 448 p. (in Russian)

13. V Ukrayini zrosli investitsiyi v okreml agroprodovolchi sektori ekonomiki. Available at: https://agropolit.com/ news/21700-v-ukrayini-zrosli-investitsiyi-v-okremi-agroprodovolchi-sektori-ekonomiki (in Ukrainian)

14. Viryanska O.V. Otsinka investitsiynoyi privablivosti. Available at: https://nau.edu.ua/site/variables/news/ 2018/5/Tezi 2018/30-).pdf (in Ukrainian)

15. Dontsov S.S. (2003) Otsinka investitsiynoyi privablivosti pidpriemstva cherez analiz nadiynosti yogo tsinnih paperiv. Finansoviy menedzhment, vol. 3, pp. 78-84. (in Ukrainian)

16. Zadorozhna Ya.E., Dyadechko L.P. (2007) Pidvischennya investitsiynoyi privablivosti pidpriemnitstva yak napryamok zaluchennya investitsiynih resursiv. Investitsiyi: praktika ta dosvid, vol. 2, pp. 32-35. (in Ukrainian)

17. Ivanov S.V. (2004) Otsinka investitsiynogo potentsialu regionu. Ekonomika: problemi teoriyi ta praktiki: zb. nauk. pr., vol. 21(191), pp. 100-103. (in Ukrainian)

18. Kapitalni investitsiyi u silske gospodarstvo u 2020 rotsi skladut blizko $36 \mathrm{mlrd}$ grn. Available at: https://agropolit.com/news/18935-kapitalni-investitsiyi-u-silske-gospodarstvo-u-2020-rotsi-skladut-blizko-36-mlrd-grn (in Ukrainian)

19. Kaplan R., Norton D. (2016) Sbalansirovannaya sistema pokazateley. Ot strategii k deystviyu. Moscow: Olimp-Biznes, 320 p. (in Ukrainian)

20. Kozyar N.O. (2019) Metodichni pidhodi do otsinki investitsiynoyi diyalnosti silskogospodarskih pidpriemstv. Agrosvit, vol. 16, pp. 67-76. (in Ukrainian) 
21. Kreynina M.N. (1994) Analiz finansovogo stanu ta investitsiynoyi privablivosti aktsionernih tovaristv u virobnitstvi, budivnitstvi ta torgivli. 256 p. (in Ukrainian)

22. Kundeus O.M. (2008) Rol investitsiynoyi privablivosti ekonomiki Ukrayini v zaluchenni Investitsiy. Innovatsiyna ekonomika, vol. 1, pp. 11-15. Available at: http://www.in.gov.ua/ (in Ukrainian)

23. Varchenko O.M., Lipkan O.V. (2016) Metodichni pidhodi do otsinki investitsiynoyi diyalnosti silskogospo-darskih pidpriemstv. Innovatsiyna ekonomika, vol. 3-4, pp. 29-38. Available at: http://nbuv.gov.ua/UJRN/ inek_2016_3-4_6 (in Ukrainian)

24. NAAN: Potreba silskogo gospodarstva $v$ investitsiyah - prinaymni $75 \mathrm{mlrd}$ grn na rik. Available at: http://naas.gov.ua/slide/naan-potreba-s-Iskogo-gospodarstva-v-nvestits-yakh-prinaymn-75-mlrd-grn-na-r-k/ (in Ukrainian)

25. Tkachenko O.M. (2018) Otsinka investitsiynoyi privablivosti Ukrayini kriz prizmu mizhnarodnih reytingiv. Investitsiyi: praktika ta dosvid, vol. 11, pp. 15-21. Available at: http://www.investplan.com.ua/pdf/11_2018/5.pdf (in Ukrainian)

26. Tkachuk I.I., Spitsina Yu.G. (2018) Sutnit ponyattya «Investitsiyna privablivist pidpriemstva». Ekonomika ta upravlinnya pidpriemstvami. Problemi sistemnogo pidhodu v ekonomitsi, vol. 5(67), pp. 124-129. (in Ukrainian)

27. U 2021 rotsi v APK ochikuetsya investitsiyniy splesk. Available at: https://agrotimes.ua/agromarket/ u-2021-roczi-v-apk-ochikuyetsya-investyczijnyj-splesk/ (in Ukrainian)

28. Sharp U.F., Aleksander G.Dzh., Beyli Dzh.V. (2001) Investitsii: uchebnik. Moscow: INFRA-M, 1035 p. (in Russian) 